\title{
Characteristics of the Incised Valley in the Jurassic of the West Junggar Basin and Its Prospect Direction, NW China
}

\author{
Kun Wang \\ Research Institute of Petroleum Exploration and Development, PetroChina, Beijing, China \\ Email: wangkuntoby@163.com
}

Received 5 July 2015; accepted 22 July 2015; published 27 July 2015

Copyright (C) 2015 by author and OALib.

This work is licensed under the Creative Commons Attribution International License (CC BY). http://creativecommons.org/licenses/by/4.0/

(c) (i) Open Access

\begin{abstract}
Incised valley is an important kind of depositional system in the Chepaizi area, west Junggar Basin. In this paper, incised valley depositional system and its prospect direction in the area were obtained with the analysis of seismic reflection, depositional and logging characters. The results show that the Chepaizi uplift Jurassic developed four kinds of filling modes including vertical aggradation, side aggradation, disorder and compound mode and three kinds of distribution type including unitary type, multiple branch type and disorder type. The fault-lithological trap can be easily formed in the updip direction of the valley with the seal of thrown side of fault, which is the main trap type in the area. Incised valley system has been confirmed to have well hydrocarbon shows, yet no industrial output was gotten. The LST fan in the underwater zone of the incised valley system in the east and south margin of the Chepaizi uplift is the important prospect direction.
\end{abstract}

\section{Keywords}

Component, Incised Valley, Depositional Character, Filling Mode, Distribution Type, Prospect Direction

Subject Areas: Sedimentology

\section{Introduction}

The incised valley is very common in extensional basin. Previous research has identified that the incised valley is an important hydrocarbon trap [1] [2]. So far, the research on incised valley in compressional basin is very limited. The Chepaizi uplift in the west Junggar Basin is located in the Forebulge belt of the rejuvenated foreland basin. In this paper, plenty of 2D, 3D seismic data coupled with drilling data and core data, the development characteristics and prospect direction of incised valley in the Jurassic were systematically studied, and the sedi- 
mentary composition, distribution and forming mechanism was obtained, which is a good theory supplement to the incised valley hydrocarbon exploration.

\section{Geological Setting}

Located in the west upwelling region of the Junggar Basin, the Chepaizi uplift is a secondary tectonic unit and belongs to the Forebulge belt of the rejuvenated foreland basin. Generally, the Chepaizi uplift is a huge long-term triangular uplift tending to the SE, mainly body of the west uplift of the Junggar Basin.

The Chepaizi uplift experienced compression and upwelling between the middle-late period of Hercynian and middle period of Yanshanian (Permian to Jurassic), resulting to the absent of strata of Permain and Jurassic. Between late period of Yanshanian and Himalayan (Cretaceous to Neogene), Thrust extrusion action resulted in multiple depression and upwelling and intense erosion of strata. Over igneous rock of the Carboniferous basement, the Jurassic Badaowan formation, Cretaceous Tugulu group, Palaeogene Anjihaihe formation, Neogene Shawan formation, and Taxihe formation was deposit in sequence (Figure 1). A series of incised valley which is composed of two systems (east margin system and south margin system) developed in the top of Jurassic strata, distributing around the foreland of paleo-uplift.

\section{The Formation Mechanism and Filling Mode of the Incised Valley}

\subsection{Formation Mechanism}

The incised valley, developing in the LST of the sequence, is contributed from the intense decrease of the accom-
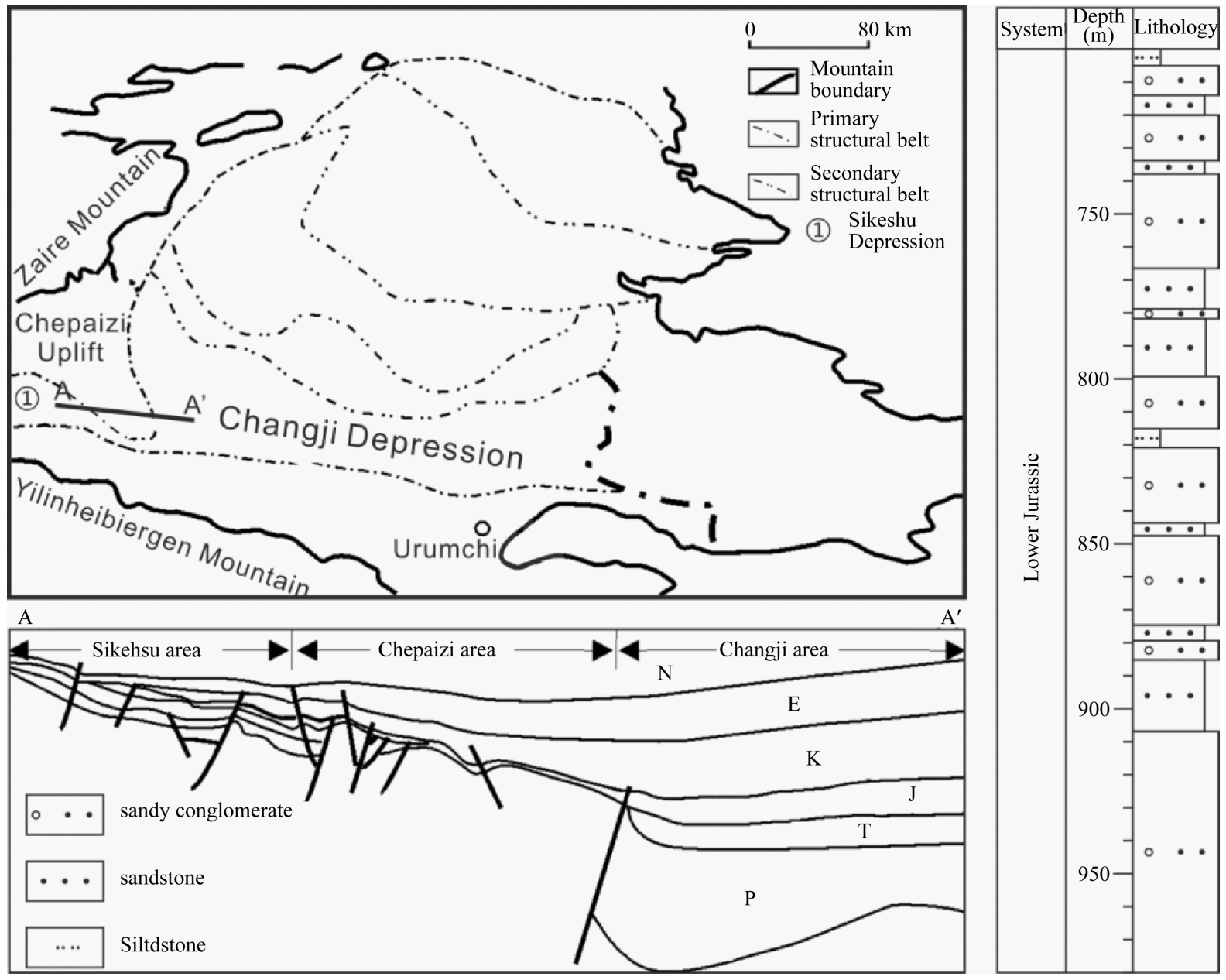

Figure 1. Tectonic setting of the Chepaizi uplift and the geological section. 
modation space. It is a good mark to identify the sequence boundary [3] [4]. Due to that the development of incised valley is caused by erosion effect of fluvial, all the factors that influence the donwcutting force can influence the formation of incised valley.

In the study area, the development and scale of incised valley is obviously influenced by basement faults. The tectonic subsidence results to the rapid increase of accommodation space of depression area, the formation of steep slope zone and the rapid decrease of accommodation of gentle slope zone. When river level drops, that is the drop of sedimentary base level, the balance of erosion effect and deposition effect is broken out, resulting to the downcutting of river and development of incised valley. When river level downs to the lowest, the scale of incised valley becomes the biggest. The incised valley in study area is different from Channel deposits of river and alluvial fan. It is a kind of large-scale river valley resulted from the decrease of erosion datum when the accommodation space in the LST rapid decreases [5] [6].

During the relative rising stage of lake level in Chepaizi area, the continuous subsidence of boundary fault resulted to the drop of steep slope zone base, causing that the deposits carried in the incised valley were not only influenced by backwater but also influenced by the tectonic subsidence in a greater degree which caused the "along-source" deposits of sand and conglomerate in the incised valley and presented progradation characteristics in section view [7] [8].

The formation pattern and scale of incised valley is controlled by the fault system of the Chepaizi area. In the plane, the incised valley distributes around the Chepaizi uplift. The east margin of Chepaizi uplift has complex fault system which resulted to the wide developing and long arborescent incised valley system. The south margin of Chepaizi uplift is relative simple, developing small short and single branch incised valley.

\subsection{Filling Mode}

Previous study shows that the incised valley has six filling mode, these are vertical aggradation, side aggradation, mound, disorder, divergence and compound mode. Because of the constraint of geological setting and seismic quality, only four styles can be seen in Chepaizi uplift, they are vertical aggradation, side aggradation, disorder and compound mode. Vertical aggradation incised valley has lentoid shape with plane top and convex bottom and has discontinuous alternative amplitude or weak amplitude in seismic section. Side aggradation incised valley also has lentoid shape with plane top and convex bottom. The inside structure has middle to weak amplitude and echelon and prograding structure, indicating the side migration character of the filling process of incised valley. The compound incised valley is the coincidence of vertical aggradation style and side aggradation style.

\section{Seismic Reflection, Sedimentary and Logging Character}

\subsection{Seismic Reflection Character}

Form the seismic section transecting the incised valley of the Chepaizi area, the valley has onlap filling and divergence filling reflection characters. The bottom has disordered reflection character with variable amplitude and frequency. The upside part of this disordered reflection layer usually presents obvious onlap filling and divergence filling character. From the section along the incised valley, the valley presents skew progradation character, indicating that during the development process, the incised valley experienced multiple vertical cutting, side erosion, consequent filling and side aggradation (Figure 2).

The shape of incised valley is backward bell-shape or U shape with symmetrical or asymmetrical wings, obviously incongruous to the plane lineups up and down. The cutting action eroded the HST fine grain deposit of under sequence; subsequently, the incongruity in the seismic data is caused by coarse grain deposits following the lake level rise.

\subsection{Sedimentary Character}

The incised valley is the main migration channel for deposits in LST and also the main deposition area for the coarse grains. The deposits grain dominated by medium-coarse sandstone in the Chepaizi uplift incised valley is generally coarse. The content of sandstone is $50 \%$ to $70 \%$, and the content of conglomerate is $30 \%$ to $40 \%$. Inside the incised valley, the deposits are dominated by gray to hoary medium-coarse sandstone and conglomeratic sandstone with laminated gray mudstone. Between the incised valleys, the deposits are mainly composed of intermittent red-brown or gray-green overflow muddy sandstone dominated by fine to medium sand grain. The 

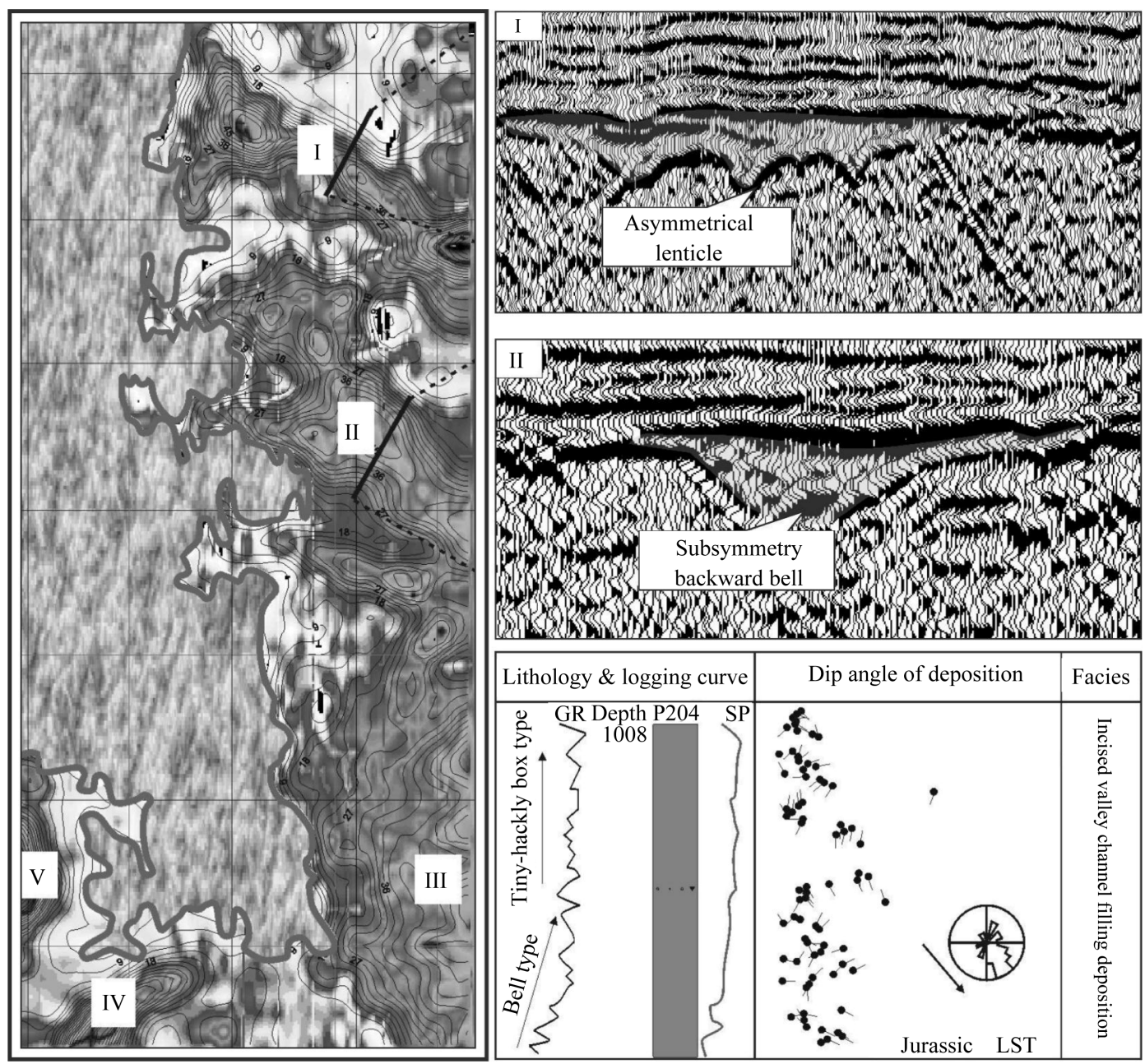

Figure 2. Seismic reflection characteristics of the incised valley in Chepaizi uplift, Junggar Basin.

sedimentary facies of upstream is alluvial fan while transits to the mixing facies of alluvial fan and braided river channel near the lake, followed by low subaqueous fan in the lakes and estuary.

The Jurassic core from depth of 575.0 to $602.8 \mathrm{~m}$ of well P6 is dominated by gray conglomerate, ranging in grain size of 50 to $150 \mathrm{~mm}$ with maximum of $700 \mathrm{~mm}$. The roundness of rubbles mainly composed of igneous rock with a few mud and sand is angular to subangular. The rubbles distribute disordered in the up part and slight parallel to the layers with imbricate structure in the bottom part of the incised valley. From the core analysis, the Jurassic deposits of P6 are the upstream channel alluvial deposit (Figure 3).

The Jurassic core from depth of 737.16 to $782.14 \mathrm{~m}$ of well P1 composed of medium to coarse sandstone, conglomerate and fine sandstone is very different from the upstream deposit. The rubbles in conglomerate which are subangular, poor sorting and disordered partly tightly arrange along the layer; besides, Erosion surfaces develop in the bottom, indicating underwater debris flow facies. The rubbles in coarse sandstone which ranging in grain size of 5 to $10 \mathrm{~mm}$ with maximum of $50 \mathrm{~mm}$ also arrange along the layer and develop massive bedding and large-scale cross bedding, which indicates underwater braided river channel facies. The rubbles in some medium to coarse sandstone have parallel bedding and graded bedding, reflecting relative strong hydrodynamic condition; while the sandstone has massive bedding and low angle cross bedding. The sedimentary character of medium to coarse sandstone indicates mouth dam facies (Figure 3).

\subsection{Logging Character}

Different part of incised valley has different logging reflection. The GR curve of alluvial fan deposits from up- 


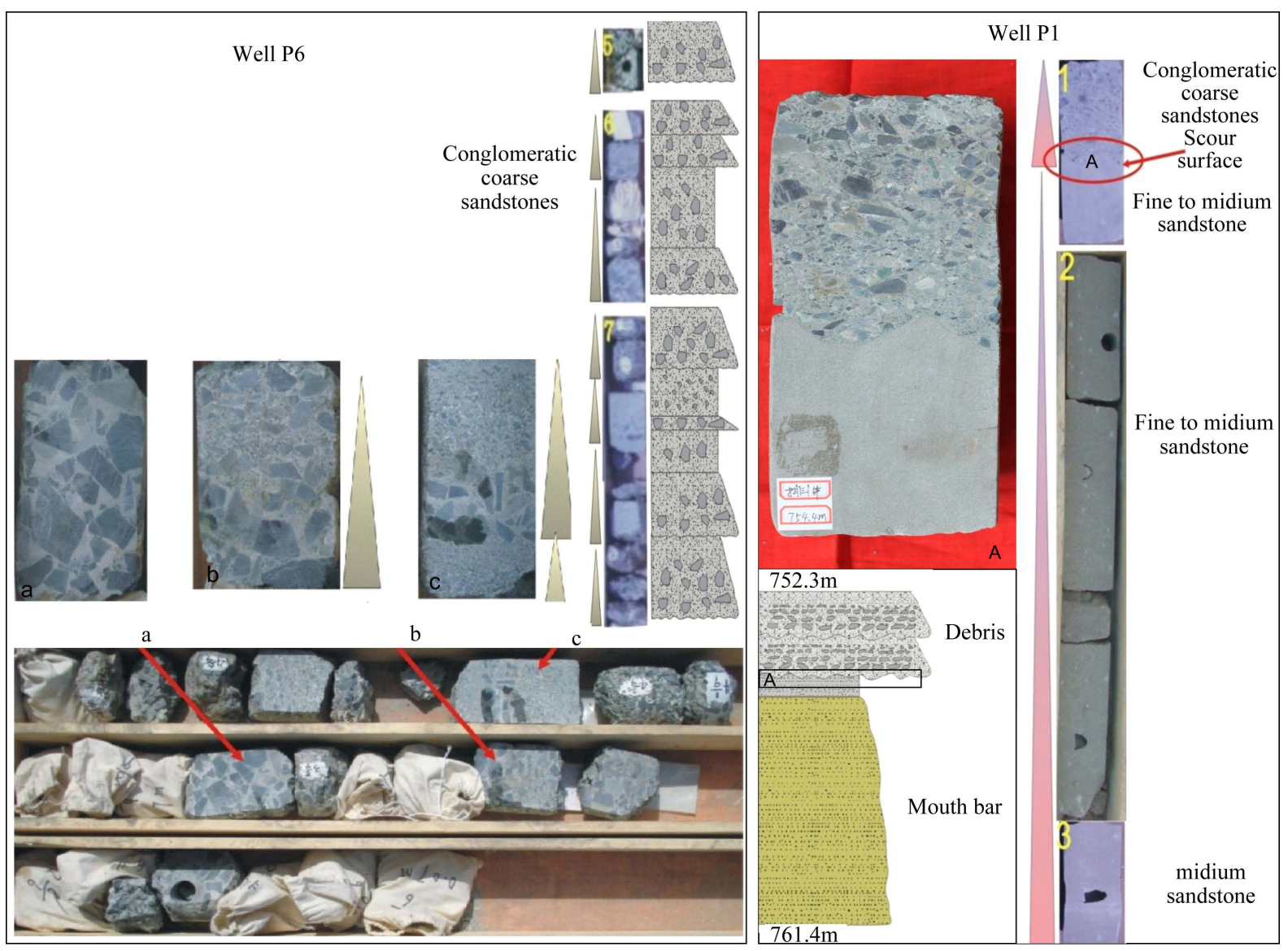

Figure 3. Sedimentary characteristics of the incised valley in Chepaizi uplift, Junggar Basin, Junggar Basin.

stream of incised valley presents hackly low amplitude box type and bell type while the GR curve of braided river channel deposits from the downstream presents smooth or tiny-hackly high amplitude box type, indicating fast stacking, strong hydrodynamic force sedimentary environment. The estuary dam facies present funnel shape in GR curve, indicating reversed graded sequence of sandstone and the gradual increase of hydrodynamic force. The underwater debris flow facies presents hackly box shape or bell shape (Figure 2).

\section{Distribution Characters of Incised Valley in Plane}

The formation and evolution of Chepaizi uplift not only controlled the paleo-geomorphology and sedimentary succession, but also controlled the fault system and incised valley system. The multiple Jurassic incised valleys distribute along the eastern and southern margin of Chepaizi uplift. These are I to V incised valley from north to south, which I, II and III incised valley belongs to eastern margin valley system and IV and V incised valley belongs to southern margin valley system.

\subsection{Eastern Margin System}

The eastern margin incised valley exhibits multiple branches character in plane and presents deep cutting symmetrical or dissymmetrical lentoid in the seismic section.

I incised valley is located at the northeast of the Chepaizi uplift, with trend of NW. At the source area, two short branch valleys formed in the uplift and jointed into one entering into the lake. The linear, NW trend valley is $5 \mathrm{~km}$ in length and over $0.5 \mathrm{~km}$. The obvious onlap phenomenon on the top of valley in seismic section represents the initial lake flooding surfaces. Inside the valley, progradation and imbricate filling deposits indicating the multiple cutting and filling process of river.

II incised valley is located at the southern of I valley and presents branch type, bifurcating, shallowing, and 
narrowing toward to the Chepaizi uplift in the west. Toward the lake in the east, branch valley joint into one deep and large scale NW trend incised valley with length similar to I valley. Multiple branch valleys can be identified in the seismic section along the flow direction.

The III incised valley located at the southeast of the Chepaizi uplift has large distribution area, crisscross branches and short extended length. Because of the gentle geography, the III valley presents fan shape in plane and wide and gentle in vertical.

\subsection{Southern Margin System}

The southern margin incised valley system is much little than the eastern margin, presenting deep cutting symmetrical lentoid shape in seismic section and linear in plane, which is unitary type incised valley system.

IV valley located at the southern of uplift linearly distributes toward south. The area is relative small and the extended length is short. V valley located at the west of IV valley has SW trend and relative short extended length. Branch valley is absent.

\subsection{Distribution Type}

The incised valley in Chepaizi uplift can be classified into 3 types: 1) unitary type, 2) multiple branch type and 3) disorder type (Figure 4). The unitary type only develops one main cutting valley with no branch, such as IV and $\mathrm{V}$ valley in the southern margin. The multiple branch type both develops main valley and branch valleys which joint into the main valley, such as I and III valley. The disordered type is similar to the second type, but the branch valleys haven't joint into the main valley, such as II incised valley.

\section{Traps and Prospect Direction}

Base on the formation mechanism and filling type analysis, it is inferred that lentoid lithological trap, pinch out lithological trap, strata onlapping trap and fault-lithological trap are the four main trap types in incised valleys.

The LST underwater fan sandstone caused by incised valley has relative fine reservoir property and usually overlapped by mudstone from the TST, which are good conditions for the accumulation of hydrocarbon in subtle reservoirs. In the updip direction of incised valley, before the migration of hydrocarbon, many faults developed cutting the valley, which are easily to form the fault-lithological trap coupled with the pinch out of lithology and seal of thrown side of fault. That kind of trap is the most important trap of the incised valley in Chepaizi uplift.

The incised valley is dominated by sand-gravel body of alluvial fan in the cores. Well P1 and P6 have drilled

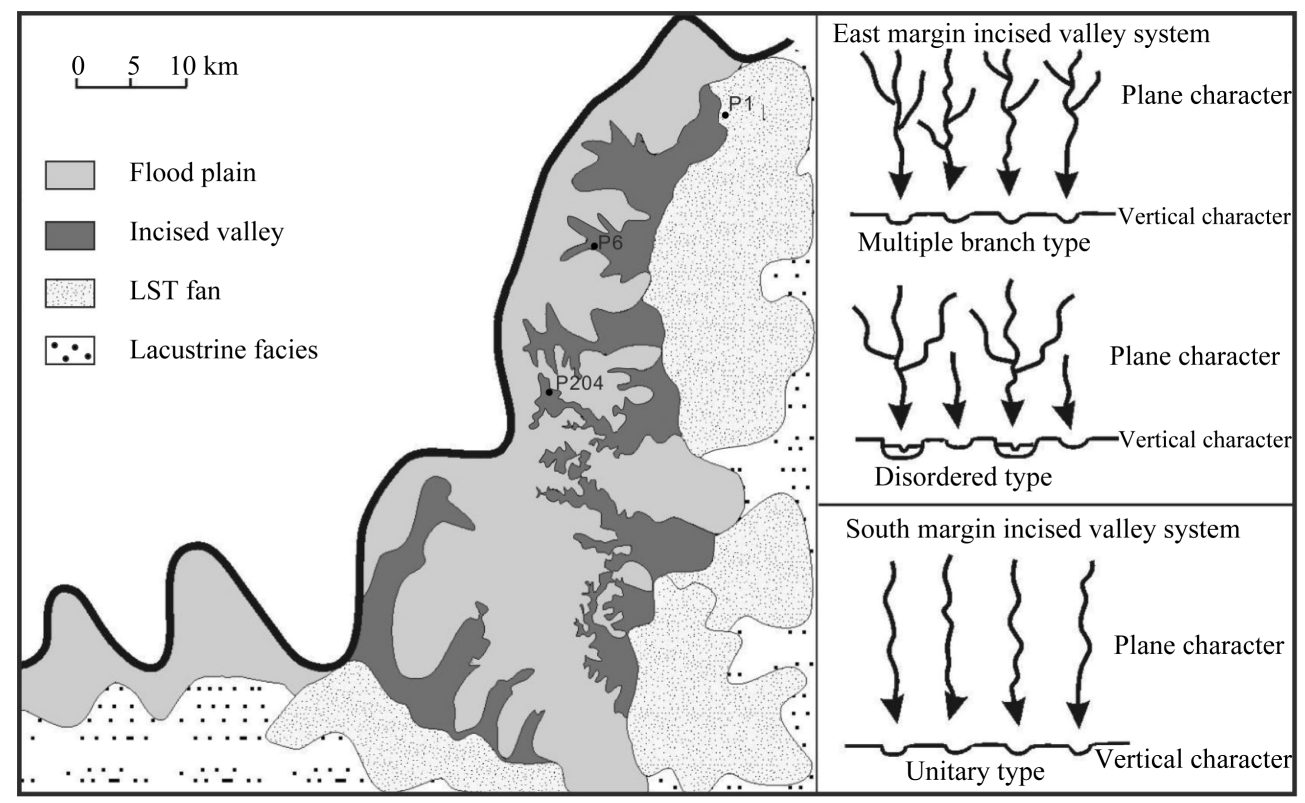

Figure 4. Distribution types of the incised valley in Chepaizi uplift. 
these deposits and have well oil shows, but no well got industrial output [9] [10]. This indicates that the incised valley has good prospect which is the important successor in the Chepaizi area; but reinforcing the research of filling style and distributing character of good reservoir is the key for the breakthrough of hydrocarbon prospect. Synthesis analysis shows that the LST fan in the downstream of incised valley have good reservoir property and migration conditions, which is easily to accumulate hydrocarbon.

\section{Conclusions}

The Chepaizi area in the west Junggar Basin developed Jurassic incised valley system which mainly distributes in the east and south margin of the uplift. Vertical aggradation, side aggradation, disorder and compound style are four filling modes. Unitary type, multiple branch type and disorder type are three distribution types.

Seismic reflection character, sedimentary character and logging character are obviously different to the surrounding deposits.

The oil shows in incised valley prove that the incised valley has good prospect. The underwater fan deposits in the incised valley system have good condition to form traps.

\section{References}

[1] Ji, Y.L. and Zhang, S.Q. (1996) Sequence Stratigraphy of Terrestrial Rifted Lake Basin. Petroleum Industry Press, Beijing.

[2] Li, S.T., Pan, Y.L. and Lu, Y.C. (2002) Key Technology of Prospecting and Exploration of Subtle Trapsin Lacustrine Fault Basins: Sequence Stratigraphic Researches on the Basis of High Resolution Seismic Survey. Journal of China University of Geosciences, 27, 592-597.

[3] Wang, S.H. (2003) Entrenched Valley and Its Significance of the Hydrocarbon Exploration Activity. Acta Geoscientica Sinica, 23, 30-32.

[4] Lin, C.S., Zhang, Y.M., Liu, J.Y., et al. (2000) High Resolution Sequence Stratingraphy and Reservoir Prediction. Earth Science Frontiers, 7, 111-117.

[5] Deng, H.W., Wang, H.L. and Ning, N. (2000) Sediment Volume Partition Principle: Theory Basis for High Resolution Sequence Stratigraphy. Earth Science Frontiers, 7, 305-314.

[6] Wagoner, J.C.V. and Bertram, G.T. (1995) Sequence Stratigraphy of Foreland Basin Deposits. AAPG Memoir 64, Tulsa.

[7] Dalrymple, R.W., Boyd, R. and Zaitlin, B.A. (1994) History of Research, Types and Internal Organization of IncisedValley Systems: Introduction to the Volume. In: Dalrymple, R.W., Boyd, R., Zaitlin, B.A., et al., Eds., Incised-Valley Systems: Origin and Sedimentary Sequences, SEPM Special Publication 51, SEPM, Tulsa. http://dx.doi.org/10.2110/pec.94.12.0003

[8] Li, T., Lu, Y.C., Chen, P. and Xiang, K. (2008) Discovery of Incised Valley and Its Petroleum Geological Significance at Chepaizi Area of the Junggar Basin. Petroleum Geology \& Experimental, 30, 363-366.

[9] Hong, T.Y., Wang, L.C., Meng, X.L. and Wu, J. (2007) The Main Control Factors of the Oil and Gas Accumulation in the Chepaizi Area of the Western Junggar Basin. Xinjiang Geology, 25, 389-393.

[10] Zhu, X.M., Zhang, Y.N., Yang, J.S., et al. (2008) Sedimentary Characteristics of the Shallow Jurassic Braided River Delta, the Junggar Basin. Oil \& Gas Geology, 29, 244-251. 